\title{
CPPU (Re-treatment), 4-CPA and NAA Improve the Growth and Quality of Parthenocarpic Melon Fruit Induced by CPPU
}

\author{
Xin-Xian Li, Yasuyoshi Hayata and Yutaka OsaJimA \\ School of Bioresources, Hiroshima Prefectural University, Shobara 727-0023, Japan
}

(Received November 5, 1999)

\begin{abstract}
Solutions of 1-(2-chloro-4-pyridyl)-3-phenylurea (CPPU), $\alpha$-napthalenacetic acid (NAA), and $p$-chlorophenoxyacetic acid (4-CPA) applied once or twice to the parthenocarpic fruit induced by CPPU at anthesis, and their effects on the growth and quality of the fruit were investigated. Non-pollinated flowers treated with CPPU produced parthenocarpic fruit with $100 \%$ fruit set. CPPU treatment at anthesis enlarged fruit until $5 \mathrm{~d}$ after anthesis, but then the growth of the fruit was exceeded by the seeded fruit (control). Both the 2nd CPPU treatments to the CPPU induced parthenocarpic fruit on the 10th day after anthesis and the 3rd CPPU treatment on the 25th day after anthesis enhanced the fruit growth. The first NAA and 4-CPA treatment to the fruit on the 10th day after anthesis and/or the second treatment on the 25th day after anthesis enhanced the fruit growth. No significant difference existed in enhancing the fruit growth between the three plant growth regulators. CPPU treatment to the pollinated flower did not influence the sugar accumulation of the fruit. The sugar content in parthenocarpic fruit induced by CPPU was significantly lower than in seeded fruit, this difference was more substantial in the placenta than in the mesocarp. Both the 2nd and 3rd CPPU treatments and the 1st and 2nd NAA treatments to the CPPU induced parthenocarpic fruit did not improve sucrose accumulation of those fruits. However, the 1st and 2nd 4-CPA treatment to these CPPU induced parthenocarpic fruit could remarkably enhanced the sugar accumulation of the fruit. These results suggest that 4-CPA treatment is practical for improving of the growth and the sugar accumulation of parthenocarpic fruit induced by CPPU.
\end{abstract}

\section{INTRODUCTION}

The percentage of fruit set on artificial pollination by hand and insect declines remarkably under the unfavorable weather, such as low temperatures and cloudy or rainy conditions (Kondo and Tanaka, 1971). To resolve this problem, plant growth regulators have been investigated as a fruit set reagent (Hayata, 1991). The study showed that 1-(2-chloro-4pyridyl)-3-phenylurea (CPPU) was dramatically effective on the fruit set of melons, and the practical technique for usage of CPPU has been already established (Tanakamaru, 1989). However, one of the author (Hayata, 1990) reported that even though CPPU application remarkably enhanced the fruit set by inducing parthenocarpy in melon fruits under a pollination inhibited condition, the growth rate and the sugar accumulation of these fruits were decreased in the latter stage of fruit growth. These points became a problem in forcing culture of melon. Then whenever CPPU is used as a fruit set reagent, artificial pollination is applied at the same time (Tanakamaru, 1989). However, artificial pollination is labor intensive and is not reliable under unstable conditions, such as low temperatures and cloudy or rainy days. It is desirable that a practical technique should be established to accelerate the growth and sugar accumulation of the parthenocarpic fruit induced by CPPU. Several reports have 
demonstrated that the pollinated melon flowers treated by auxin-like substances such as $\alpha$-naphthaleneacetic acid (NAA) and p-chlorophenoxyacetic acid (4-CPA) enhanced the enlargement of fruits (Kondo and Tanaka, 1971; Elassar et al., 1974; Takayama, 1976; Shikano, 1979 ; Masuda et al., 1990). But there have been few studies which tested whether plant growth regulators could enhance the growth and sugar accumulation of the parthenocarpic fruits.

The present experiment was undertaken to investigate whether CPPU, NAA or 4-CPA could improve the growth and sugar accumulation of the parthenocarpic fruit induced by CPPU treatment.

\section{MATERIALS AND METHODS}

Plant culture. Muskmelon (Cucumis melo L. cv. Crest Earl's) was used in this experiment. Eighty-eight seedlings were transplanted $45 \mathrm{~cm}$ apart in 2 lines $(1.2 \mathrm{~m}$ wide $\times 20 \mathrm{~m}$ long bed) in a greenhouse at Hiroshima Prefectural University from 15th July through 6th November, 1998. Air temperature in the greenhouse was controlled between 18 and $28^{\circ} \mathrm{C}$ by a heating system (NEPON KA-201, Nepon Ltd.). Watering in the bed was automatically controlled by an irrigation system regulated by a tensionmeter (DM-8P Melon, Takemura Electric Works Ltd.). The soil moisture tension ( $\mathrm{pF}$ ) was maintained at $\mathrm{pF} 1.8$ until flowering $(28 \mathrm{~d}), \mathrm{pF} 2.0$ from flowering until fruit set $(7 \mathrm{~d}), \mathrm{pF} 1.8$ during rapid fruit growth stage $(20 \mathrm{~d}), \mathrm{pF} 2.0$ from net formation stage until $7 \mathrm{~d}$ before harvest $(33 \mathrm{~d})$, then $\mathrm{pF} 2.4$ until harvest (7 d), respectively. Fertilizer was applied twice, the first application was a preplant broadcast application of $30 \mathrm{~N}-30 \mathrm{P}-40 \mathrm{~K}(\mathrm{~kg} / \mathrm{ha})$ and the second application was a sidedress application of $15 \mathrm{~N} \mathrm{~kg} / \mathrm{ha}$ at anthesis. The vines (main shoots) were grown upwards and topped at the 26th node. All lateral vines between the 13th node and 15th node of the main shoots were cut above the 2 nd node. Other lateral vines were removed. Fruit set percentage was recorded at $10 \mathrm{~d}$ after treatment and the fruits were thinned to leave only one per plant.

Treatment. Solutions of $20 \mathrm{ppm}$ CPPU were sprayed to the ovaries of the flowers on the first nodes of lateral vines both in the pollinated and non-pollinated plots at anthesis. The non-pollinated flowers were covered with paper bags from $1 \mathrm{~d}$ before anthesis to $3 \mathrm{~d}$ after anthesis. Then, the parthenocarpic fruits induced by CPPU in the non-pollinated plot were applied the solutions of $20 \mathrm{ppm}$ CPPU, $100 \mathrm{ppm}$ NAA or $100 \mathrm{ppm} 4-\mathrm{CPA}$ once or twice at 10 $\mathrm{d}$ after anthesis and/or $25 \mathrm{~d}$ after anthesis. In total there were 9 plots with 8 seedlings, respectively. The treatments are shown in Table 1.

Growth and peel color measurement. Fruit length was measured with a caliper at 1 or $5 \mathrm{~d}$ intervals from anthesis to harvest. The fruit weight and the peel color (by Chroma meter ; CR-200, Minolta) were measured at harvest. Peel hue $\left({ }^{\circ}\right)$ was calculated according to McGuire (1992).

Sugar analysis. The fruits were cut vertically into two halves, and a $5 \mathrm{~g}$ tissue was removed from both the centers of the placenta and mesocarp regions by cutting with a razor, and then crushed in a mortar. The aliquots containing the soluble sugars were passed through a membrane filter $(0.45 \mu \mathrm{m})$, and $10 \mu \mathrm{L}$ of the filtrate was injected into a high performance liquid chromatography system (Shimadzu LC, Gilson 133 RI refractive index detector). Sugars were separated on a Shodex Asahipak NH2P-50 4E column (Showadenko Co., Tokyo) at $40^{\circ} \mathrm{C}$ with $65 \%$ acetonitrile solution $(1 \mathrm{~mL} / \mathrm{min})$.

\section{RESULTS AND DISCUSSION}

The rate of fruit set for the pollinated control was 57\%, while an application of CPPU on the pollinated and non-pollinated flowers at anthesis dramatically increased the fruit set to over $98 \%$. The proportion of normal seeds in the control fruits was $86 \%$, although that of 
CPPU-treated pollinated flowers decreased to 69.4\%. Application of CPPU to nonpollinated flowers induced parthenocarpy in melon fruits, leaving the seed coats behind in the center (Table 1). During the first $5 \mathrm{~d}$ after anthesis, CPPU treatment enhanced the fruit growth in both the pollinated and non-pollinated flowers, but on the 6th day after anthesis the growth of CPPU-treated fruit was exceeded by the control fruit. Thereafter, the growth rate of the pollinated fruits treated with CPPU was similar to that of the control. Whereas the growth rate of the non-pollinated fruits that were treated with CPPU at anthesis was slowed, and the fruits became smaller than in the control fruits (Fig. 1). These results were similar to

Table 1 Effects of CPPU, 4-CPA and NAA treatment on the weight, the color and the seed of CPPU induced parthenocarpic fruits.

\begin{tabular}{|c|c|c|c|c|c|c|c|c|}
\hline & \multicolumn{3}{|c|}{ Treatment } & \multirow{2}{*}{$\begin{array}{l}\text { Fruit weight } \\
\text { (g) }\end{array}$} & \multirow{2}{*}{$\begin{array}{c}\text { Peel color } \\
\text { degree } \\
\left({ }^{\circ}\right)\end{array}$} & \multirow{2}{*}{$\begin{array}{c}\text { Fruit set } \\
\text { (\%) }\end{array}$} & \multirow{2}{*}{$\begin{array}{c}\text { Total seed } \\
\text { number }\end{array}$} & \multirow{2}{*}{$\begin{array}{c}\text { Empty } \\
\text { seed ratio } \\
\text { (\%) }\end{array}$} \\
\hline & $0 \mathrm{DAA}^{z}$ & 10DAA & $25 \mathrm{DAA}$ & & & & & \\
\hline Control & $P^{y}$ & & & $1166 \mathrm{a}^{\mathrm{t}}$ & $89 \mathrm{c}$ & $57 \mathrm{~b}$ & 780 & 14 \\
\hline PC & $\mathrm{P}+\mathrm{C}^{\mathrm{x}}$ & & & $1225 \mathrm{a}$ & $106 \mathrm{~b}$ & $98 \mathrm{a}$ & 514 & 31 \\
\hline $\mathrm{NC}$ & $\mathrm{C}^{\mathrm{w}}$ & & & $963 \mathrm{~b}$ & $113 \mathrm{a}$ & $100 \mathrm{a}$ & 665 & 100 \\
\hline NCC & $\mathrm{C}$ & $+\mathrm{C}$ & & $1225 \mathrm{a}$ & $108 \mathrm{~b}$ & $100 \mathrm{a}$ & 737 & 100 \\
\hline $\mathrm{NC} 2 \mathrm{C}$ & $\mathrm{C}$ & $+\mathrm{C}$ & $+\mathrm{C}$ & $1272 \mathrm{a}$ & $113 \mathrm{a}$ & $100 \mathrm{a}$ & 697 & 100 \\
\hline NCCPA & $\mathrm{C}$ & $+\mathrm{CPA}^{\mathrm{v}}$ & & $1225 \mathrm{a}$ & $110 \mathrm{ab}$ & $100 \mathrm{a}$ & 619 & 100 \\
\hline $\mathrm{NC} 2 \mathrm{CPA}$ & $\mathrm{C}$ & $+\mathrm{CPA}$ & $+\mathrm{CPA}$ & $1241 \mathrm{a}$ & $109 \mathrm{~b}$ & $100 \mathrm{a}$ & 606 & 100 \\
\hline NCNAA & $\mathrm{C}$ & $+\mathrm{NAA}^{\mathrm{u}}$ & & $1238 \mathrm{a}$ & $113 \mathrm{a}$ & $100 \mathrm{a}$ & 565 & 100 \\
\hline NC2NAA & $\mathrm{C}$ & + NAA & $+\mathrm{NAA}$ & $1276 \mathrm{a}$ & $111 \mathrm{ab}$ & $100 \mathrm{a}$ & 543 & 100 \\
\hline
\end{tabular}

${ }^{2}$ Days after anthesis.

y Pollination.

${ }^{x}$ Pollination and CPPU 20 ppm treatment.

${ }^{w}$ Non-pollination and CPPU 20 ppm treatment.

$\checkmark$ 4-CPA 100 ppm treatment.

u NAA 100 ppm treatment.

${ }^{\mathrm{t}}$ Significant differences $(0.01)$ using an analysis of variance followed by LSD testing.

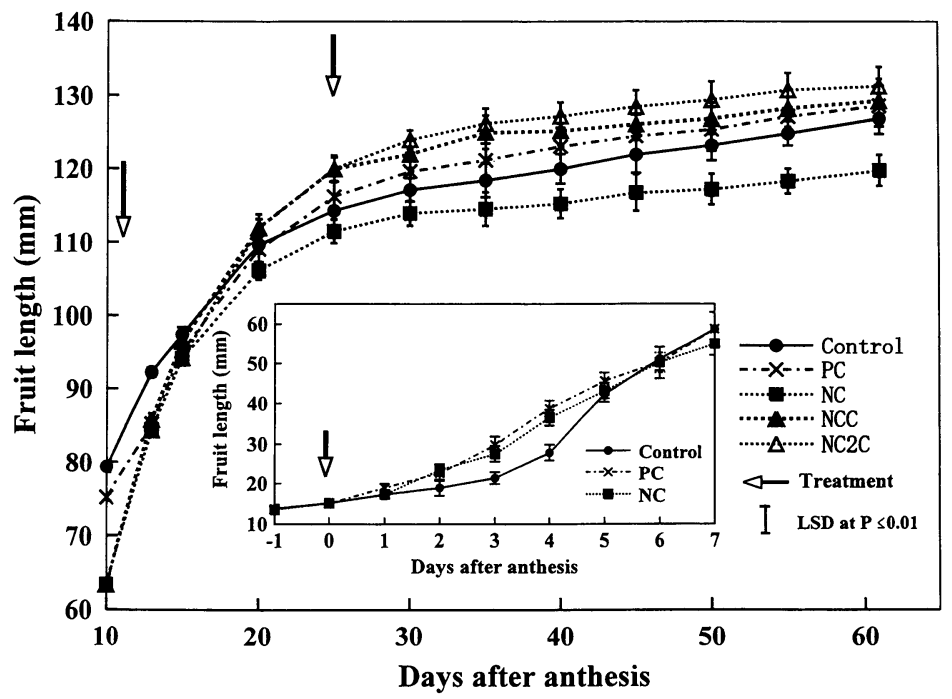

Fig. 1 The growth of CPPU induced parthenocarpic fruits as influenced by CPPU re-treatment in fruit enlargement.

Control: pollination; PC : pollination +20 ppm CPPU treatment; NC: non-pollination +20 ppm CPPU treatment. 


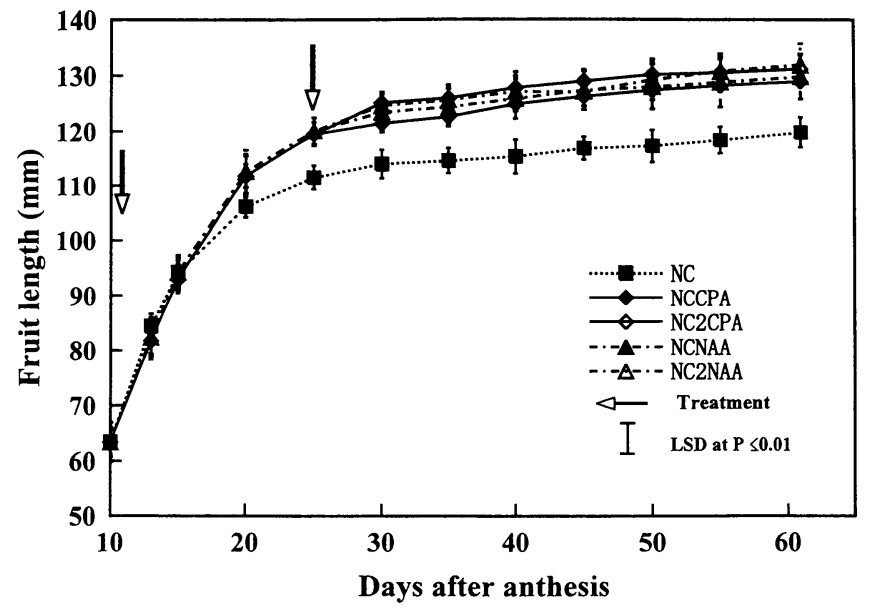

Fig. 2 Effect of 4-CPA and NAA treatment on the growth of CPPU induced parthenocarpic fruits. NC: non-pollination +20 ppm CPPU treatment; NCCPA : NC $+100 \mathrm{ppm} 4-\mathrm{CPA}$ treatment at 10th day after anthesis; NC2CPA : NC $+100 \mathrm{ppm}$ 4-CPA treatment at 10th day after anthesis + 4-CPA replication at 25 th day after anthesis; NCNAA : NC +100 ppm NAA treatment at 10th day after anthesis; NC2NAA : NC +100 ppm NAA treatment at 10 th day after anthesis + NAA replication at 25 th day after anthesis.

Table 2 Effects of CPPU, 4-CPA and NAA treatment on the sugar contents of CPPU induced parthenocarpic fruits.

\begin{tabular}{|c|c|c|c|c|c|c|c|c|}
\hline \multirow[b]{2}{*}{ Treatment $^{2}$} & \multicolumn{4}{|c|}{ Mesocarp } & \multicolumn{4}{|c|}{ Placenta } \\
\hline & $\begin{array}{c}\text { Sucrose } \\
(\%)\end{array}$ & $\begin{array}{c}\text { Glucose } \\
\text { (\%) }\end{array}$ & $\begin{array}{c}\text { Fructose } \\
(\%)\end{array}$ & $\begin{array}{c}\text { Total } \\
(\%)\end{array}$ & $\begin{array}{c}\text { Sucrose } \\
\text { (\%) }\end{array}$ & $\begin{array}{c}\text { Glucose } \\
\text { (\%) }\end{array}$ & $\begin{array}{c}\text { Fructose } \\
(\%)\end{array}$ & $\begin{array}{c}\text { Total } \\
(\%)\end{array}$ \\
\hline Control & $8.70 \mathrm{ab}^{\mathrm{y}}$ & $2.13 \mathrm{bc}$ & $1.94 \mathrm{bc}$ & $12.77 \mathrm{ab}$ & $9.37 \mathrm{a}$ & $0.65 \mathrm{ab}$ & $0.91 \mathrm{a}$ & $10.93 \mathrm{a}$ \\
\hline PC & $9.17 \mathrm{a}$ & $1.99 \mathrm{c}$ & $1.86 \mathrm{c}$ & $13.02 \mathrm{ab}$ & $10.05 \mathrm{a}$ & $0.73 \mathrm{ab}$ & $0.92 \mathrm{a}$ & $11.70 \mathrm{a}$ \\
\hline $\mathrm{NC}$ & $6.93 \mathrm{~cd}$ & $2.59 \mathrm{abc}$ & $2.34 \mathrm{ab}$ & $11.85 \mathrm{bc}$ & $5.60 \mathrm{~d}$ & $0.55 \mathrm{ab}$ & $0.83 \mathrm{ab}$ & $6.98 \mathrm{~d}$ \\
\hline $\mathrm{NCC}$ & $6.13 \mathrm{~d}$ & $2.61 \mathrm{ab}$ & $2.39 \mathrm{a}$ & $11.12 \mathrm{c}$ & $6.32 \mathrm{~cd}$ & $0.71 \mathrm{a}$ & $0.83 \mathrm{ab}$ & $7.86 \mathrm{~cd}$ \\
\hline $\mathrm{NC} 2 \mathrm{C}$ & $6.93 \mathrm{~cd}$ & $2.67 \mathrm{a}$ & $2.48 \mathrm{a}$ & $12.07 \mathrm{abc}$ & $7.23 \mathrm{~cd}$ & $0.64 \mathrm{ab}$ & $0.97 \mathrm{a}$ & $8.84 \mathrm{bc}$ \\
\hline NCCPA & $7.42 \mathrm{~cd}$ & $2.40 \mathrm{abc}$ & $2.33 \mathrm{ab}$ & $12.15 \mathrm{abc}$ & $7.83 \mathrm{bc}$ & $0.47 \mathrm{ab}$ & $0.70 \mathrm{~b}$ & $9.00 \mathrm{bc}$ \\
\hline NC2CPA & $8.71 \mathrm{ab}$ & $2.30 \mathrm{abc}$ & $2.15 \mathrm{abc}$ & $13.16 \mathrm{a}$ & $9.11 \mathrm{ab}$ & $0.62 \mathrm{ab}$ & $0.79 \mathrm{ab}$ & $10.52 \mathrm{ab}$ \\
\hline NCNAA & $7.67 \mathrm{bc}$ & $2.24 \mathrm{abc}$ & $2.18 \mathrm{abc}$ & $12.09 \mathrm{abc}$ & $7.02 \mathrm{~cd}$ & $0.39 \mathrm{~b}$ & $0.63 \mathrm{~b}$ & $8.04 \mathrm{~cd}$ \\
\hline NC2NAA & $7.01 \mathrm{~cd}$ & $2.20 \mathrm{abc}$ & $2.15 \mathrm{abc}$ & $11.37 \mathrm{c}$ & $6.41 \mathrm{~cd}$ & $0.42 \mathrm{~b}$ & $0.65 \mathrm{~b}$ & $7.48 \mathrm{~cd}$ \\
\hline
\end{tabular}

${ }^{z}$ These letters indicate treatments as same as Table 1 .

${ }^{y}$ Significant differences $(0.01)$ using an analysis of variance followed by LSD testing.

those in the previous report (Hayata, 1990), although the used melon cultivar was different. Nitsch (1952) suggested that the fruit size and shape are closely correlated with the seed number and their distribution inside a fruit in many plants. Therefore, one of the factors responsible for stimulating the growth rate of melon fruits is thought to be the number of seeds in a fruit. In this study, it was confirmed that CPPU could enhance the fruit set and fruit growth during the short period after inducing parthenocarpy in melons. The same observation in watermelons has been reported (Hayata et al., 1995).

The authors examined whether any treatment using CPPU, 4-CPA and NAA once or twice could recover the slowdown of fruit growth and the decrease of accumulation of sugar in the parthenocarpic fruit (Fig. 2). The 2nd CPPU treatment was applied to the CPPU induced parthenocarpic fruits on the 10th day after anthesis, and it promoted fruit growth 
equal to the control fruits. Moreover, the $3 \mathrm{rd}$ CPPU treatment to the fruit at $25 \mathrm{~d}$ after anthesis tended to be more effective in promoting fruit growth compared with the 2nd CPPU treatment, although there was no significant difference between the 2 nd and 3 rd treatments. In many fruits, CPPU brings significant increase in fruit growth, such as grapes (Nickell, 1986), kiwifruits (Iwahori et al., 1988; Ogata et al., 1988), and pears (Banno et al., 1986). This experiment demonstrated that CPPU retreatment promotes fruit growth in parthenocarpic melon fruit. NAA and 4-CPA treatment also enhanced the growth of parthenocarpic fruits, and the growth patterns were similar to that of the 2nd and 3rd CPPU treated fruit. Elassar (1974) reported that 4-CPA treatment to non-pollinated muskmelon ovaries at anthesis promoted ovary development. No significant difference existed in enhancing the fruit growth between the three plant growth regulators. Takayama (1976) reported that NAA treatment to pollinated ovaries at full bloom promoted ovary development. In this experiment, 4-CPA and NAA has the ability to promote non-pollinated ovary development. Furthermore, a timely application of these growth regulators effectively enlarged the parthenocarpic fruit induced by CPPU treatment.

With regard to the sugar content, sucrose is the main sugar in melon fruit (Table 2). There are little differences in this sugar content in both mesocarp and placenta between the CPPU-treated pollinated fruit and the pollinated fruit (control). The results indicate that CPPU can not affect the sugar contents of the seeded fruit. In both the placenta and mesocarp of the parthnocarpic fruit induced by CPPU, the sucrose content tended to be low, especially in the placenta where the sucrose levels were particularly low (5.6\%), compared with the control (seeded fruit), reaching was $9.4 \%$. These results suggest that the decrease of sugar content in the parthenocarpic fruit can not be attributed merely to the CPPU treatment, but is resulted from the absence of seeds. Hence, it is thought that seeds play an important role in promoting sink activity of the fruit, which is essential for an accumulation of sugars in the fruit. The 2nd and 3rd CPPU treatment and NAA treatments could not increase sucrose accumulation in both the mesocarp and the placenta of the parthenocarpic fruit, whereas 4-CPA treatment at $10 \mathrm{~d}$ after anthesis promoted it. Furthermore, the 2nd 4-CPA treatment at $25 \mathrm{~d}$ after anthesis significantly promoted sucrose accumulation compared with the single treatment at $10 \mathrm{~d}$ after anthesis, and consequently the sugar content of these fruits became almost similar to that of the seeded fruit. The amount of glucose and fructose in the mesocarp of parthenocarpic fruits was slightly higher than in the seeded fruit, although the sugar content in the placenta tended to be low. The difference in the total sugar content of the mesocarp between the seeded fruits and seedless fruit diminished, while the difference in the sugar content of placenta tended to be increased. Peel color is one of the fruit qualitative factors. The color of CPPU-treated fruits was greener $\left(106-113^{\circ}\right)$ compared to the control $\left(89^{\circ}\right)$. 4-CPA improved the color of non-pollinated fruit with CPPU treatment, but the other plant growth regulators did not (Table 1).

In this experiment, 4-CPA was effective to improve the growth and sugar accumulation of the parthenocarpic fruits that were induced by CPPU treatment at anthesis. Therefore, it is suggested that 4-CPA applications to the fruit after fruit set by CPPU may be a practical technique when pollination is limited such as in low temperatures and cloudy or rainy conditions. The future study should investigate the role of sugar metabolic enzymes in melon fruits as it relates to the promotion of growth and the accumulation of sugar in the combined treatments of CPPU at anthesis and 4-CPA at the fruit enlargement.

\section{REFERENCES}

Banno, K., Hayashi, S., Tanabe, K. 1986. Effect of KT-30 spray on the growth and quality of pear fruit. (Japanese text) Abstr. Jpn. Soc. Hortic. Sci. Autumn Meet. 55 : 521-522. 
Elassar, G., Rudich, J., Kedar, K. 1974. Parthenocarpic fruit development in muskmelon induced by growth regulators. HortScience 9 : 579-580.

Hayata, Y. 1990. The effect of cytokinin on the fruit set and sugar accumulation of melon fruit. (Japanese text) Abstr. Jpn. Soc. Hortic. Sci. Autumn Meet. 59: 370-371.

Hayata, Y. 1991. The use of plant growth regulators vs. the growth and quality of fruit. In "The System of Agricultural Technology, Melon and Watermelon.” (Japanese text) Soc. Cult. Agric. Vill. Press, Tokyo, p 227-236.

Hayata, Y., Niimi, Y., Iwasaki, N. 1995. Synthetic cytokinin-1-(2-chloro-4-pyridyl)-3-phenylurea (CPPU)- promotes fruit set and induces parthenocarpy in watermelon. J. Amer. Soc. Hortic. Sci. 120 : $997-1000$.

Iwahori, S., Tominaga, S., Yamasaki, T. 1988. Stimulation of fruit growth kiwifruit, Actinidia chinensis Planch., by N-(2-chloro-4-pyridyl)-N'-phenylurea, a diphenylurea-derivative-cytokinin. Sci. Hortic. 35 : $109-115$.

Kondo, Y., Tanaka, Y. 1971. Studies on the artificial fruit setting of the Cucumis melo L. (I) On the effect of growth regulator treatments. (Japanese text) Fukuoka Hortic. Exp. Stn. Bull. 10:53-60.

Masuda, M., Nagao, N., Matsubara, S. 1990. Growth and sugar contents of 2,4-D-induced parthenocarpic melon fruits cv. 'Earl's Favourite.' (Japanese text with English abstract) Bull. Okayama Agric. Coll. $75: 15-21$.

McGuire, R. G. 1992. Reporting of objective color measurements. HortScience $27: 1254-1255$.

Nickell, L. G. 1986. The effect of N-(2-chloro-4-pyridyl)-N'-phenylurea on grapes and other crops. Proc. Plant Growth Regulat. Soc. Amer. 13 : 236-241.

Nitsch, J. P. 1952. Plant hormones in the development of fruits. Q. Rev. Biol. 27 : 33-57.

Ogata, R., Saito, T., Oshima, K. 1988. Effect of N-phenyl-N'-(4-pyridyl) urea (4-pu) on fruit size : apple, Japanese pear, grapevine, and kiwi fruit. Acta Hortic. 239 : 395-398.

Shikano, S. 1979. Effects of auxin application and material of bags on net formation and quality of musk melon fruits cropped through summer and autumn. (Japanese text with English abstract) Miyagi Agric. Coll. Bull. 27 : 12-18.

Takayama, G. 1976. Promoting fruit set of melon. (Japanese text) Agric. Hortic. 45: 839-840.

Tanakamaru, K. 1989. Development and characteristics of new plant growth regulator [Fulmett solution]. (Japanese text) Agric. Chem. 36: 40-46.

\section{〈和文抄録〉}

\section{CPPU(再処理)，4-CPA および NAA 処理によるCPPUによって誘導されたメロン 単為結実果の生長と品質の改善}

\section{李 新賢・早田保 義・筬島 豊}

広島県立大学生物資源学部

CPPU 再処理および 4-CPA またはNAA 処理が, CPPUによって誘導されたメロン単為結実果 の生長と品質におよほす影響を調査した．開花時の CPPU 処理は受粉および未受粉花の着果率を 著しく増加させ, 特に未受粉花区では CPPU が単為結果を誘導し, 100\%の着果率となった. CPPU 処理は果実の発育初期における生長量を急激に増大させたが, 処理後 5 日目には対照区の生長速 度が処理区に比べ高まり, 収穫時の単為結実果は小果となった. 単為結実果生育中の CPPU の再処 理, 4-CPA およびNAA の 1 回または 2 回処理は, 果実の生長速度を回復させ, 収穫時には対照区 とほほ同程度の果実重量となった。 また, それら生長調節物質間に回復効果の差は認められなかっ た. CPPU 処理によって誘導された単為結実果の糖含量は対照区に比べ低下したが(胎座部で著し い), 4-CPA の 1 回または 2 回処理が単為結実果の糖含量を増加させ, 収穫時には対照区果実とほ ほ同程度の糖含量となった. CPPU 再処理およびNAA 1 回または 2 回処理には果実の糖含量を増 加させる効果はなかった. 受粉・受精の不適環境条件下で生じやすい果実の肥大量低下や糖含量の 低下に対する対策として，4-CPA の利用が有効な手段となる可能性が推察された。 